\title{
Dolphins distributions (Mammalia: delphinidae) in an upwellings zone (Chile)
}

\author{
Distribución de delfines Mammalia: \\ delphinidae) en una zona de surgencias (Chile)
}

\author{
M. Buscaglia ${ }^{1}$, W. Sielfeld ${ }^{2} \&$ A. Aguayo-Lobo ${ }^{3}$
}

\begin{abstract}
The results of a study on sighting frequency and relative abundance of delphinids along the coast of Northern Chile (18 $30^{\prime} S-25^{\circ} 23^{\prime}$ 'S; from coast to $70^{\circ} 27^{\circ} \mathrm{W}$ ), conducted between March and December 2000 in an area of $207.614,60 \mathrm{~km}^{2}$ are reported. The following eight species were sighted: Short-beaked Common Dolphin (Delphinus delphis), Long-beaked Common Dolphin (Delphinus capensis), Shortfinned Pilot Whale (Globicephala macrorhynchus), Risso's Dolphin (Grampus griseus), Dusky Dolphin (Lagenorhynchus obscurus), Southern Right Whale Dolphin (Lissodelphis peronii), Striped Dolphin (Stenella coeruleoalba) and Bottlenose Dolphin (Tursiops truncatus). The distribution of dolphins north of Tocopilla showed relationship with the coastal upwelling front of that area, while off the Mejillones Peninsula the relative abundance and diversity of dolphins was associated with the extensive upwelling plume described for this area.
\end{abstract}

T. truncatus was the most frequently sighted species (44.14\% 111 herds) and represented $59.6 \%$ of the total observed specimens. L. peronii $(15.10 \%)$ and L.obscurus (8.22\%) follows numerically. Other species were represented by $<4 \%$ of the total observed specimens.

The here found species are common to the Peruvian coast. Missing species are Phocoena spinipinnis, a more coastal species than the area covered by the present survey and Pseudorca crassidens, Feresa attenuata, Peponocephala electra and Stenella longirostris, which are from warmer waters and associated with the Paracas area. This study provides a first estimate of the distribution and relative abundance of small cetaceans of the upwelling ecosystem of Northern Chile.

\section{Key words:}

Delphinus delphis, Delphinus capensis, Globicephala macrorhynchus, Grampus griseus, Lissodelphis peronii.

\section{Resumen}

Se comunican los resultados de un estudio de frecuencias de avistamiento y abundancias relativas de delfínidos a lo largo de la costa norte de Chile (18 $30^{\circ} \mathrm{S}-25^{\circ} 23^{\prime} \mathrm{S}$; desde la costa hasta $70^{\circ} 27^{\circ} \mathrm{O}$ ), realizado entre marzo y diciembre de 2000 en un área de 207.614,60 $\mathrm{km}^{2}$. Las siguientes especies fueron avistadas: delfín común de rostro corto (Delphinus delphis), delfín común de rostro largo (Delphinus capensis), ballena piloto de aleta corta (Globicephala macrorhynchus), delfín gris (Grampus griseus), delfín oscuro (Lagenorhynchus obscurus), delfín liso (Lissodelphis peronii), delfín listado (Stenella coeruleoalba) y trursión (Tursiops truncatus). La distribución de delfines al norte de Tocopilla mostró

1 Centro Universitario de Coyhaique,

Universidad de Magallanes, Coyhaique, Chile.

marxbuscaglia@gmail.com

2 Departamento de Ciencias del Mar,

Universidad Arturo Prat, Iquique, Chile.

凸 walter.sielfeld.kowald@gmail.com

3 Departamento Científico del Instituto Antártico Chileno,

Chile.

aaguayo@inach.cl 
estar relacionada con el frente de surgencia de ese sector, mientras que frente a la Península de Mejillones las abundancias relativas y la diversidad de delfines estuvieron asociadas con la extensa pluma de surgencia descrita para dicha área.

T. truncatus fue la especie más frecuentemente avistada (44,14\% de 111 rebaños) y representada por $59,6 \%$ del total de individuos observados. $L$. peronii $(15,10 \%)$ y L. obscurus $(8,22 \%)$ siguen numéricamente, mientras que otras especies solo presentaron $<4 \%$ del total de individuos estudiados. Las especies aquí encontradas son compartidas con las costas de Perú. Especies faltantes son Phocoena spinipinnis, una especie más costera que el área cubierta en el presente estudio, y Pseudorca crassidens, Feresa attenuata, Peponocephala electra y Stenella longirostris, que son de aguas más temperadas y asociadas al área en torno a Paracas. Este estudio representa la primera estimación de abundancias relativas de pequeños cetáceos para ecosistema de surgencias del norte de Chile.

\section{Palabras clave:}

Delphinus delphis, Delphinus capensis, Globicephala macrorhynchus, Grampus griseus, Lissodelphis peronii .

\section{INTRODUCTION}

The Humboldt Current System (HCS) is one of the most productive marine ecosystems on Earth (Barnes \& Hughes, 1988; Escribano \& McLaren, $1999)$ and extends from Southern Chile ( 42 ${ }^{\circ}$ ) up to Ecuador and the Galapagos Islands (Thiel et al. 2007), characterized by dominant equatorward alongshore wind stress, offshore Ekman transport and coastal upwelling of cold, nutrientrich subsurfase water into the photic zone. The primary production can reach up to $9.3 \mathrm{~g} \mathrm{C} \mathrm{m}^{-2} \mathrm{~d}^{-1}$ (Daneri et al. 2000).

Upwelling in Northern Chile (north of $\sim 42^{\circ} \mathrm{S}$ ) appears to vary little with season and is a year-round feature (Morales et al. 1996), but related to local winds at periods about 3-10 days (Shaffer et al. 1997; Torres et al. 1999).

The coastal topography (e.g. points, capes) and bottom topography also affects the coastal upwelling circulation (Graham \& Largier, 1997;
Trowbridge et al. 1998), generating at a mesoscale important upwelling centers along the $18-22^{\circ} \mathrm{S}$ study area that can be identified as Península Mejillones, Punta Patache, Punta Chucumata, Punta Pisagua, Punta Camarones (Lagos et al. 2002; Marín \& Moreno, 2002; Marín et al. 2003; Escribano et al. 2002, 2009).

The upwelling plumes of these centers can extend up to $50 \mathrm{~km}$ offshore (case of Mejillones Peninsula: Rodríguez et al. 1991; Marín et al. 2001; Sobarzo \& Figueroa, 2001) and its interaction with the poleward Peruvian CounterCurrent (PCC) may influence and exert a southward flow in Peruvian and northern Chilean waters up to 100-300 km from the coast (Silva, 1983; Strub et al. 1998), resulting in areas offshore and south of the upwelling focus that are relatively productive for oceanic feeders (Rendell et al. 2004) and creating a particularly productive habitat for fish spawning, eggs and larvae (Rojas et al. 2002) and in consequence feeding grounds for sea mammals.

This system is considered to be the most productive in terms of fish biomass, estimated to support a long-term production twenty times higher than the Benguela and Canary current systems (Marzloff \& Tam, 2011) and supports the Chilean pelagic fishery, principally based on landings of anchovy, mackerel and pilchard, with total annual landings up to 6,9 million T between $18^{\circ} 25^{\prime} \mathrm{S}$ $56^{\circ} 30^{\prime}$ S (Thiel et al. 2007). But anchovy landings are most important in Northern Chile (Administrative Regions XV, I and II) with annual landings up to 2 million $T$ in 1994-95 and around 0,5-1 annual $T$ in last decades (SUBPESCA, 2016), with frequent interactions and incidental capture of top depredators, mainly otariids, but also in lower rates sea birds, sea turtles and small cetaceans (Böhm et al. 2017).

The knowledge of small odontocetes in the HCS, particularly delphinids, is inadequate (Clarke, 1962; Cárdenas et al. 1986; Aguayo-Lobo, 1999), although there are numerous studies that provide valuable local background on small cetaceans (Aguayo, 1975; Gallardo \& Pastene, 1983; Guerra et al. 1987 b; Van Waerebeek \& Guerra, 1987, 1988; González et al. 1989; Cárdenas et al. 1991; Canto et al. 1992; Sanino et al. 2003a, b; Sielfeld et al. 2003).

In the Chilean sector of the HCS (south of $\left.18^{\circ} \mathrm{S}\right)$, Delphinidae is represented by nineteen 
species (Aguayo, 1975; Sielfeld, 1983; Cárdenas et al. 1986; Guerra et al. 1987a, b; Canto et al. 1992; Aguayo-Lobo et al. 1998a; Hucke-Gaete, 2000), eight of which inhabit the neritic-littoral zone. Abundance indexes off Chile have only been calculated for few of these species (Aguayo-Lobo et al., op. cit), but the population size of most part of these species in the southeast Pacific is unknown.

Estimates of cetacean abundance and population density are key to assessing potential effects of anthropogenic perturbations on cetacean populations (Carretta et al. 2006) and in understanding the ecological role of cetaceans in marine ecosystems (Trites et al. 1997). However, there is little published information on current abundance to evaluate direct anthropogenic impacts on cetacean species and to estimate their food requirements (Barlow \& Forney, 2007), aspects currently fundamental to regulate the by catch, the incidental death and other direct damages associated with the anchovy purse seine fishing of Northern Chile, the food needs of top depredators to ensure the implementation of the "ecosystem management concept" adopted by the "Nueva Ley de Pesca y Acuicultura de Chile" (Ley 18.892 y modificaciones de la Ley 21.134 del 16/02/2019) (Chilean Fishing Law), and to support the Protection programs for the various vulnerable and/or endangered species (sea turtles, birds, sea mammals).

Consequently the present paper focuses on the presence and relative abundances of delphinid species off Northern Chile, to contribute to understand the distribution and abundance of small cetacean in the northern part of the Humboldt Current ecosystem, comprising the following objectives: 1) identify the species, 2) evaluate their distribution, 3) analyze the species relative abundances and 4) the relationship with the upwellings.

\section{MATERIALS AND METHODS}

\section{Study area}

The cruise was off Northern Chile (18 $30^{\circ} \mathrm{S}-25^{\circ} 23^{\prime} \mathrm{S}$; from coast to $70^{\circ} 27^{\circ} \mathrm{W}$ ) (Fig. 1). This areas is influenced by the Mejillones Peninsula that impacts the spatial distribution of winds and currents, reinforces the coastal upwelling and modifies the latitudinal distribution of the Ekman transport (Letelier et al. 2012) and defined as a local biogeographic unit of the transitional zone between Northern and Central Chile, whose southern limit is $30^{\circ} \mathrm{S}$ (Camus, 2001). It also represents the southern distribution limit for various coastal fishes (Sielfeld et al. 2010) and fishing stocks as the case of the anchovy (CCTPP, 2014). The coastline north of the Mejillones Peninsula $\left(23^{\circ} \mathrm{S}\right)$ is relatively straight, and aligned primarily in a north-south direction and a large part of the biological productivity develops in a narrow strip along the coast (Fig. 2), particularly in areas of active upwelling between $18^{\circ}-35^{\circ} \mathrm{S}$ (Fonseca \& Farías, 1987; Fonseca, 1989; Vergara, 1991, 1992; Strub et al. 1998).

\section{Equipments}

The data were collected from the $13 \mathrm{~m}$ sailing vessel "Balaena" from March to December 2000 (Appendix 1). The surveys used acoustic searching with an omni-directional hydrophone (Benthos AQ4 with Ithaco pre-amplifiers). During daylight (7:00 $-18: 30=11.5 \mathrm{~h}$ ) only, visual searching by a staff of three independent observers ordered in three shifts of $4 \mathrm{hr}$. Date, hour and geographic position were recorded automatically every 5 min using a Trimble Transpak and Garmin 65 GPS navigator.

\section{Cruises}

The present study corresponds with an annex result of the Project of Sound Recording on Sperm whale (Rendell et al. 2004). Details of the general navigation track were given by Whitehead (2003) and Rendell et al. (op. cit.) and totaled 158 days at sea during 9 cruises (Table 1) at monthly intervals during year 2000 .

Due to operational reasons related to supply and base port the survey area was divided in the following sectors: following $18^{\circ} 30$ r $-19^{\circ} 59^{\prime} \mathrm{S}$ (Sector 1: Arica-Pisagua), 20-22 29'S (Sector 2: Iquique-Tocopilla), $22^{\circ} 30$ r $^{2} 3^{\circ} 59^{\prime} \mathrm{S}$ (Sector 3: Mejillones-Antofagasta) and $24^{\circ}-25^{\circ}, 30^{\circ} \mathrm{S}$ (Sector 4: El Cobre-Taltal) (-Figs. 1, 3; Appedix 1).

During navigation straight segments between georeferenced start and end points were considered as "transects", with length expressed in km. Hundred and two of these units were surveyed, totaling 9.703,2 


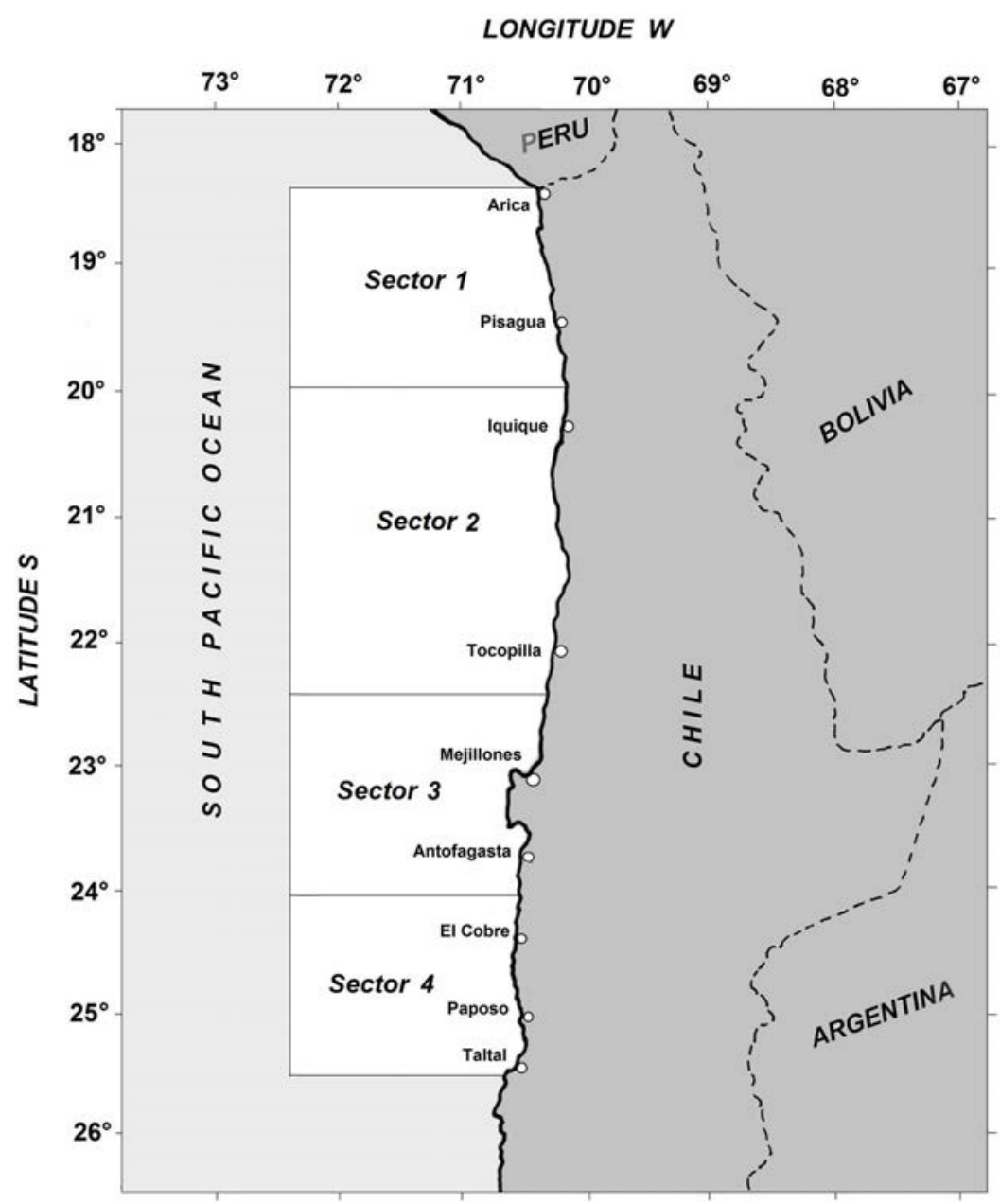

Fig. 1. Study area (in white) and transect grouping sectors (Zones 1-4).

$\mathrm{km}(=5 \cdot 239,3$ nautical miles). Fig. 3 shows navigation track and transects. The distance $(\mathrm{Km})$ between points was estimated using the Vincenty equation (1975) to calculate distances on spheroidal surfaces in geodesy. For distribution data analyses the transects were ordered north south by geographical degree.

T.obs. = total observation hours; M.day = mean of daily observation time; T.obs.b. = total observation hours during good conditions; $b=$ daily mean with good sea and weather conditions.

\section{Species}

Taxonomic identification of individuals was corroborated following the Review of Small Cetaceans of Culik (2004) and The Sierra
Club Handbook of Whales and Dolphins of Leatherwood et al. (1983). Special attention was given to the short-beaked Delphinus delphis and the long-beaked $D$. capensis that were distinguished by the less crisp and colorful colour pattern of the first one (Perrin, 2002). The nomenclature used followed Aguayo-Lobo et al. (1998a).

\section{Sightings}

Species identification and group size were recorded independently by each of the three observers of the corresponding shift. The raw data expressed in Appendix 1 represent a numerical average between the records of the three observers. The sightings were assisted with $10 \times 50$ binoculars and a Canon EOS 


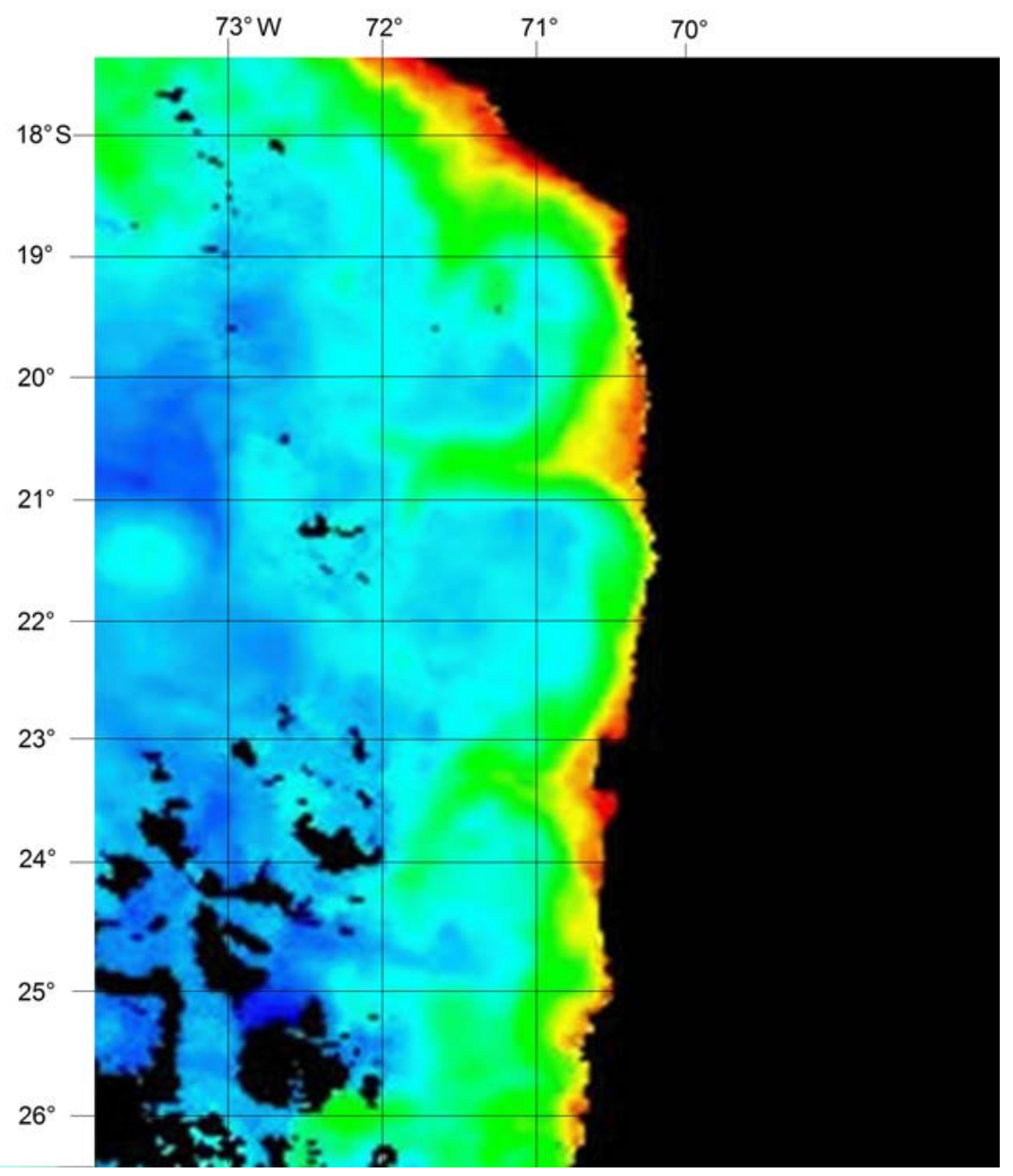

Chlorophyll Concentration, OC3 Algorithm (mg m³

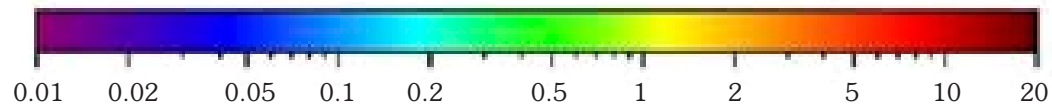

Fig. 2. Chlorophyll concentration during March 2000 off the north coast of Chile. Composition of monthly data. Source: NASA Goddard Space Flight Center, Ocean Ecology Laboratory, Ocean Biology Processing Group; (2014): Sea-viewing Wide Field-of-view Sensor (SeaWiFS) Ocean Color Data, NASA OB.DAAC. https://doi.org/10.5067 / ORBVIEW-2 / SEAWIFS_ OC.2014.0. Accessed on 2019/04/17.

Table 1. Sighting effort by sighting trip between March and December 2000 off Northern Chile.

\begin{tabular}{ccccccc}
\hline Campaigns & Dates & Days $(\mathrm{n})$ & T.obs. & M.day & T.obs.b. & M.day b. \\
\hline 1 & $28 / 03-17 / 04$ & 21 & 241.5 & 11.5 & 188.5 & 8.98 \\
2 & $25 / 04-16 / 05$ & 21 & 241.5 & 11.5 & 184.5 & 8.79 \\
3 & $24 / 05-14 / 06$ & 22 & 195.5 & 11.5 & 171.5 & 10.26 \\
4 & $26 / 06-09 / 07$ & 14 & 184.0 & 11.5 & 110.0 & 6.88 \\
5 & $14 / 07-03 / 08$ & 21 & 241.5 & 11.5 & 215.5 & 10.26 \\
6 & $18 / 08-05 / 09$ & 19 & 195.5 & 11.5 & 137.5 & 8.09 \\
7 & $26 / 09-17 / 10$ & 12 & 230.0 & 11.5 & 177.5 & 8.88 \\
8 & $26 / 10-13 / 11$ & 9 & 195.5 & 11.5 & 127.5 & 7.50 \\
9 & $22 / 11-10 / 12$ & 19 & 218.5 & 11.5 & 184.0 & 9.68 \\
\hline TOTALS & $28 / 03-10 / 12$ & 158 & $1,943.5$ & 11.5 & $1,496.5$ & 8.70 \\
\hline
\end{tabular}



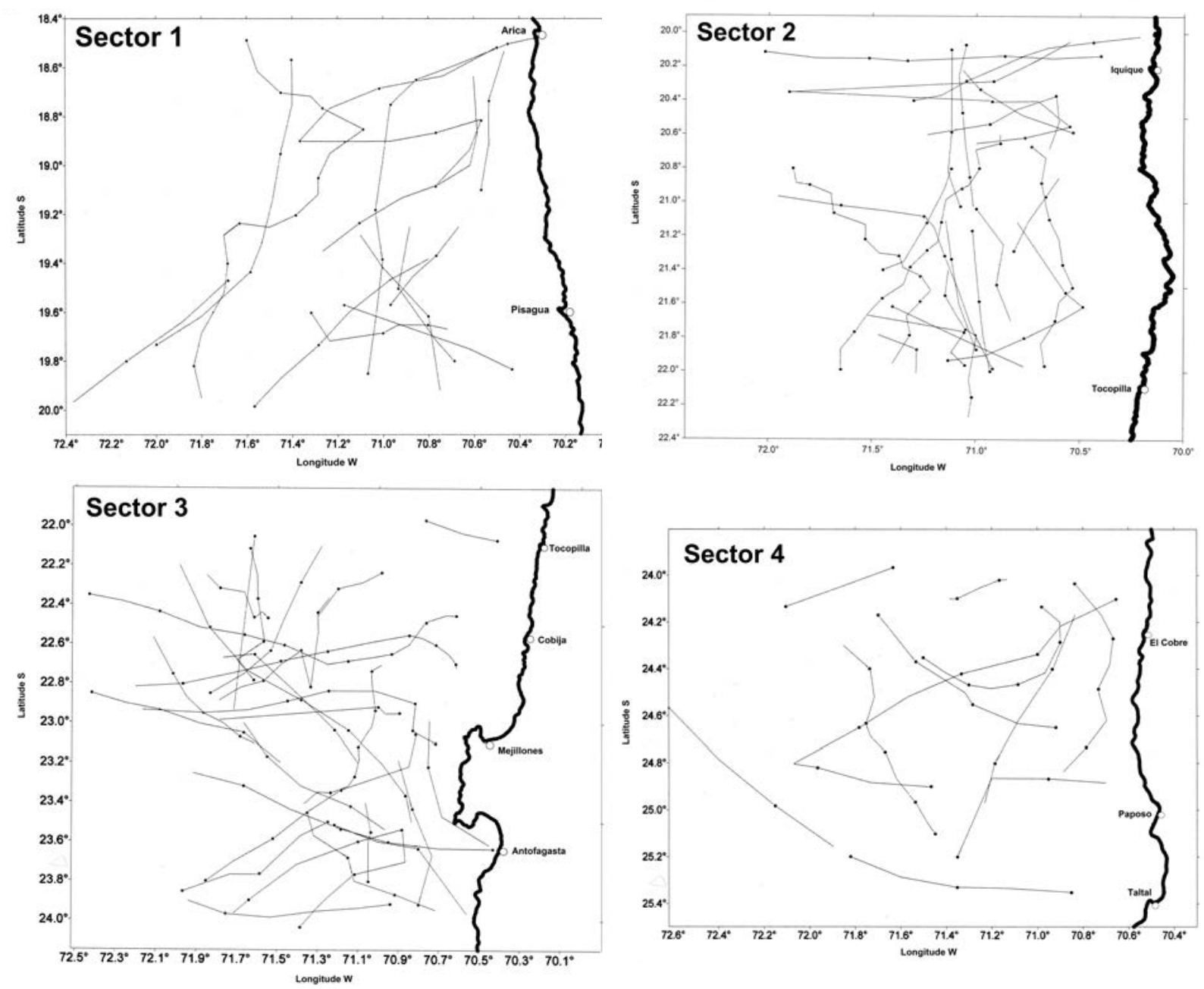

Fig. 3. Navigation tracks and sighting transects: Sector 1: Arica-Pisagua $\left(18.4-20.0^{\circ} \mathrm{S} / 70.4\right.$ $-72.4^{\circ} \mathrm{W}$ ); Sector 2: Iquique-Tocopilla (20.2-22. $\left.4^{\circ} \mathrm{S} / 70.5-72.0^{\circ} \mathrm{W}\right)$; Sector 3: Mejillones-Antofagasta (22.0-24.0 $\left.{ }^{\circ} \mathrm{S} / 70.5-72.5^{\circ} \mathrm{W}\right)$; Sector 4: El Cobre Taltal $\left(24.0-25.4^{\circ} \mathrm{S} / 70.6-72.6^{\circ} \mathrm{W}\right)$.

3000 camera with a 75-300 zoom, and digitalized with Surfer Software (WIN 32), version 6.04. Total sightings during the complete cruise are summarized in Table 1 and sightings for each transect in Table 2. Each sighting consisted in: 1) species identification, 2) herd size and 3) estimated distance to first observation point. The sightings were expressed as Sighting Rate (individuals a/o herds/day).

\section{Statistical analyses}

Using average effort (hours of observation with good observation conditions/days at sea $=\leq$ Beaufort 4 and calm to moderate breeze)
(Table 1) an "sighting (or encounter) rate" was calculated for each species following AguayoLobo et al. (1998b) and Hucke-Gaete (1998), expressed in sightings/day (times a species was sighted each day) and animals/day (individuals of each species sighted during a day). The estimation of these values was considered important by allowing comparisons with the results presented by the previous authors.

Interpretation of species distribution patterns was supported by Kernel distribution maps (Gaussian Function; 95\% concentration ellipses level) from PAST 2.17 Statistical Programme (Hammer, 2018). 


\section{RESULTS}

\section{Species observed}

Small cetacean herd sightings were made, corresponding to 5.841 individuals of 8 dolphin species: Short-beaked Common Dolphin (Delphinus delphis) (Dd), Long-beaked Common Dolphin (Delphinus capensis) (Dc), Short-finned Pilot Whale (Globicephala macrorhynchus) $(\mathrm{Gm})$, Risso's Dolphin (Grampus griseus) (Gg), Dusky Dolphin(Lagenorhynchusobscurus) (Lo), Southern Right Whale Dolphin (Lissodelphis peronii) (Lp), Striped Dolphin (Stenella coeruleoalba) (Sc) and Bottlenose Dolphin (Tursiops truncatus) (Tt) (Appendix 1).

\section{Association between species}

The $21.62 \%$ of the recorded specimens (1.263 of 5.841 ind.) integrated herds of more than one species. Nineteen herd sightings $(17.12 \%)$ and 269 specimens (4.61\%) were observed in association with sperm whales (Physeter catodon) and 2 groups (44 individuals) were found with Otaria byronia (Appendix 1).

Seven groups (565 individuals) were associated with sea birds, of which 505 were $L p$ from the sector in front of Mejillones (2324-38'S) (Appendix 1, Table 1).

Associations between delphinid species were mainly represented by associations with $T t: 1$ case with $G g$ off Arica $\left(18^{\circ} 49^{\prime} \mathrm{S}\right), 1$ case with $S c$ off

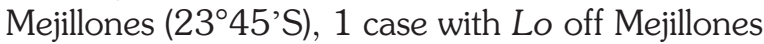
$\left(23^{\circ} 03^{\prime} \mathrm{S}\right)$ and 5 cases with $\mathrm{Gm}$ between $21^{\circ} 55^{\prime}$ -

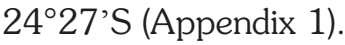

\section{Sightings}

$T t$ was the most frequently sighted species (44.14\%; 49 of the 111 herds) and represented $59.6 \%$ of the total observed specimens (3.481 out of a total of 5.841$). L p(\mathrm{n}=882 ; 15.10 \%)$ and Lo ( $\mathrm{n}=480 ; 8.22 \%)$ follows numerically. Other species were represented by $<4 \%$ of the total observed specimens (Table 2).

\section{Latitudinal distribution of species}

The principal dolphin sightings were around $21^{\circ} 00^{\prime}-21^{\circ} 59^{\prime} \mathrm{S}(12.7 \%)$ in sector 2 and $23^{\circ} 00^{\prime}-23^{\circ} 59^{\prime} \mathrm{S}(68.6 \%)$ in sector 3 (Table 2; Fig. 4a). Other sectors were represented by $\leq 5 \%$.
Regarding herd sightings $39.6 \%$ around $23^{\circ} 00^{\prime}$ 2359'S (Table 2).

The sighting of specimens per species in the latitudinal perspective $\left(18-25^{\circ} \mathrm{S}\right)$ (Table 2) shows that $D d$ was concentrated mainly around $18^{\circ} 00^{\prime}-18^{\circ} 59^{\prime} \mathrm{S}(48.8 \%)$ and $21^{\circ} 00^{\prime}-21^{\circ} 59^{\prime} \mathrm{S}$ (34.2\%), Dc concentrated around $21^{\circ} 00^{\prime}$ $21^{\circ} 59^{\prime} S$ (92.6\%), $G m$ and $G g$ respectively concentrated $85.6 \%$ and $92.3 \%$ of their observations between $21^{\circ} 00$ )- $23^{\circ} 59$ 'S (Fig. 4c), Lo $88.5 \%$ at $23^{\circ} \mathrm{S}, \mathrm{Lp} 100 \%$ at $23^{\circ} 00 \mathrm{r}^{-} 24^{\circ} 59^{\prime} \mathrm{S}$. $T t$ was the only species represented along the entire latitudinal gradient, however with $61.3 \%$ of individuals sighted at around $23^{\circ} 00^{\prime}-23^{\circ} 59^{\prime} \mathrm{S}$ (Fig. 4b). The only sighting of $S c$ was also made in that sector.

This trend is also repeated if herds are considered (Table 2), where the highest percentages of herd sighting of $G g, G m, L p, L o, S c$ and $T t$ is coincident with the sectors indicated for specimen numbers. Exceptions are $D d$ and $D c$ where the respective higher abundances were in the $18^{\circ}$ and $21^{\circ}$ sector, resulting from the existence of greater herds in that sectors.

\section{Latitudinal species assemblage composition changes}

The species structure (\%) expressed by geographical degree (Table 3) shows Tt (59.6\%) and $L p(15.1 \%)$ as the most sighted species. Along the latitudinal gradient $\left(18^{\circ}-25^{\circ} \mathrm{S}\right)$ the predominant species was Tt, except around 18 00 ; $-18^{\circ} 59^{\prime} \mathrm{S}$ in which $D d$ stood out (> 75\%) and around $24^{\circ} 00^{\prime} \mathrm{S}-24^{\circ} 59^{\prime} \mathrm{S}$ where it is surpassed by $L p$ (58.3\%).

The $18^{\circ} 00-18^{\circ} 59, \mathrm{~S}$ sector with a predominant presence of $\mathrm{Dd}(75.2 \%), 19^{\circ}-23^{\circ} \mathrm{Tt}$ $(44.7-84.7 \%)$ and $23^{\circ} 00^{\prime}-24^{\circ} 59^{\prime} \mathrm{S}$, presence of $L p(18.4-58.9 \%)$ and in general by greater number of species. The sightings expressed in number of herds is not consistent with the above, except $T t$ that stands out with $30.0-62.5 \%$ over the sighting of herds of the other species.

\section{Sighting Rates (specimens and/or herds/day)}

For the total sighting records $T t$ showed the highest sighting rate (22.0 ind./day; 0.31 herds/ day). The remaining species had values $\leq 0.05$ herds/day and $\leq 5$ ind./day (Table 4). 
Table 2. Sightings (herds and individuals) expressed as \% and arranged by degree of latitude.

\begin{tabular}{|c|c|c|c|c|c|c|c|}
\hline \multicolumn{8}{|c|}{ Individuals } \\
\hline Species & $\begin{array}{l}18^{\circ} 00^{\prime}- \\
18^{\circ} 59^{\prime}\end{array}$ & $\begin{array}{l}19^{\circ} 00^{\prime}- \\
19^{\circ} 59^{\prime}\end{array}$ & $\begin{array}{l}20^{\circ} 00^{\prime}- \\
20^{\circ} 59^{\prime}\end{array}$ & $\begin{array}{l}21^{\circ} 00^{\prime}- \\
21^{\circ} 59^{\prime}\end{array}$ & $\begin{array}{l}22^{\circ} 00^{\prime}- \\
22^{\circ} 59^{\prime}\end{array}$ & $\begin{array}{l}23^{\circ} 00^{\prime}- \\
23^{\circ} 59^{\prime}\end{array}$ & $\begin{array}{l}24^{\circ} 00^{\prime} \\
24^{\circ} 59^{\prime}\end{array}$ \\
\hline D. delphis & 48.78 & 2.44 & & 34.15 & & & 14.63 \\
\hline D. capensis & & 2.47 & & 92.59 & & & 4.94 \\
\hline G. macrorhynchus & 5.93 & & & 14.41 & 25.42 & 45.76 & 8.47 \\
\hline G. griseus & 7.75 & & & 38.76 & 6.98 & 46.51 & \\
\hline L. obscurus & & & 8.33 & & 3.13 & 88.54 & \\
\hline L. peronii & & & & & & 83.22 & 16.72 \\
\hline S. coeruleoalba & & & & & & 100.00 & \\
\hline T. truncatus & 0.46 & 4.60 & 4.60 & 11.26 & 6.55 & 70.96 & 1.58 \\
\hline Indet. & & 5.42 & 11.92 & 16.26 & 4.34 & 61.25 & 0.81 \\
\hline Total & 2.28 & 3.24 & 4.18 & 12.65 & 5.09 & 68.21 & 4.35 \\
\hline \multicolumn{8}{|c|}{ Herds } \\
\hline Species & $\begin{array}{l}18^{\circ} 00^{\prime}- \\
18^{\circ} 59^{\prime}\end{array}$ & $\begin{array}{l}19^{\circ} 00^{\prime}- \\
19^{\circ} 59^{\prime}\end{array}$ & $\begin{array}{l}20^{\circ} 00^{\prime}- \\
20^{\circ} 59^{\prime}\end{array}$ & $\begin{array}{l}21^{\circ} 00^{\prime}- \\
21^{\circ} 59^{\prime}\end{array}$ & $\begin{array}{l}22^{\circ} 00^{\prime}- \\
22^{\circ} 59^{\prime}\end{array}$ & $\begin{array}{l}23^{\circ} 00^{\prime}- \\
23^{\circ} 59^{\prime}\end{array}$ & $\begin{array}{l}24^{\circ} 00^{\prime}- \\
24^{\circ} 59^{\prime}\end{array}$ \\
\hline D. delphis & 25.00 & 25.00 & & 25.00 & & & 25.00 \\
\hline D. capensis & & 33.33 & & 33.33 & & & 33.33 \\
\hline G. macrorhynchus & 11.11 & & & 11.11 & 22.22 & 44.44 & 11.11 \\
\hline G. griseus & 16.67 & & & 33.33 & 16.67 & 33.33 & \\
\hline L. obscurus & & & 11.11 & & 11.11 & 77.78 & \\
\hline L. peronii & & & & & & 77.78 & 22.22 \\
\hline S. coeruleoalba & & & & & & 100.00 & \\
\hline T. truncatus & 4.08 & 4.08 & 20.41 & 18.37 & 16.33 & 30.61 & 6.12 \\
\hline Indet. & & 4.76 & 23.81 & 14.29 & 9.52 & 38.10 & 9.52 \\
\hline Total & 4.50 & 4.50 & 14.41 & 15.32 & 12.61 & 39.64 & 9.01 \\
\hline
\end{tabular}

Campaign 8 (October/November $=$ spring) standed out with the highest sighting rate (313.7 ind./day) and campaign 4 (June/July = winter) with the lowest value (7.1 ind./day) (Table 4) mainly due to the dominant presence of $T t$ (2.341 individuals; $82.9 \%$ of all individuals in the campaign).

\section{Herd size}

Aggregations were generally quite variable, ranging from 1 individuals $(T t)$ to 250 individuals $(L p)$ (Table 5). The species with the largest herds was $L p$ (average $=122,5$ individuals), though herd size for this species varied considerably (ranging from 1 to 250; $\mathrm{SD}=112,06)$. Large aggregations were also noted for $T t$ (2-160 ind.; average 36,1 ind.) and Dd (8-150 ind.; average 52,6 ind.). The numerically most important herds (Tt 2.470, Lp 734, Lo 425) (Appendix 1) were observed around $24^{\circ} 00$ )-2459)S.

\section{DISCUSSION}

The recorded species are the same found by Van Waerebeek et al. (1988) for the littoral zone of Peru, with the exceptions of Phocoena spinipinnis (typical of coastal habitats, and incompletely covered by the present survey), Pseudorca crassidens, Feresa attenuata, Peponocephala electra and Stenella longirostris, which are from warmer waters and associated with the Paracas area and/or the northern region of Peru.

All these species have been previously cited for the study area by Aguayo (1975) 
a

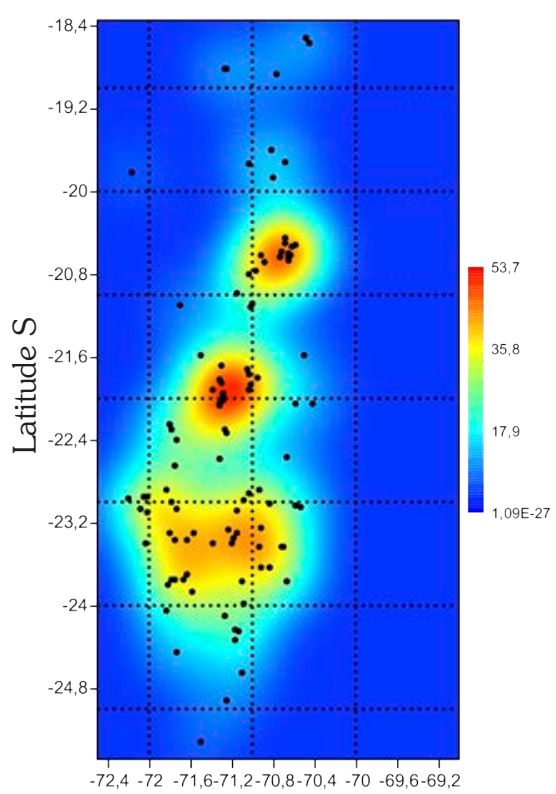

b

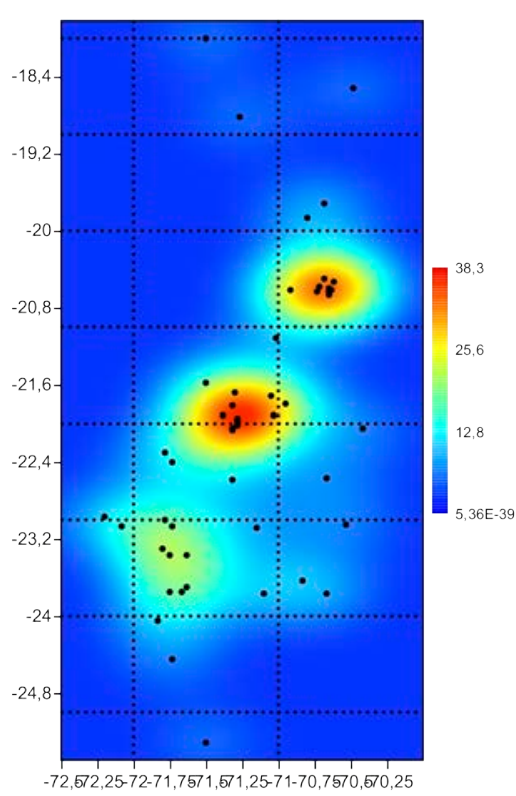

Longitude $\mathrm{W}$ c

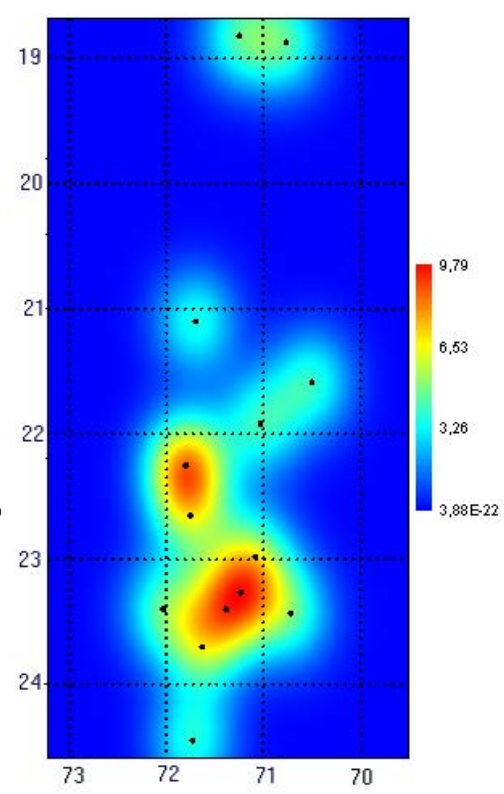

Fig. 4. Kernel density maps (Gaussian function, concentration ellipses level 95\%):

a. all species; b. Tursiops truncatus; c. Globicephala macrorhynchus and Grampus griseus.

and Aguayo-Lobo et al. (2002). AguayoLobo et al. (1998 a,b) cited Delphinus capensis, D. delphis, Feresa attenuata, Globicephala macrorhynchus, Globicephala melas, Grampus griseus, Lagenorhynchus obscurus, Lissodelphis peronii, Orcinus orca, Pseudorca crassidens, Stenella coeruleoalba, Steno bredanensis and Tursiops truncatus for the northern area of Chile. The lack of observations of Feresa attenuata in the present study is probably explained by its preference for subtropical and tropical waters, as noted by Hoyt (1999).

All the present Globicephala sightings were positively identified as G. macrorhynchus. Globicephala melas, the most abundant dolphin in the Humboldt Current System (Clarke et al. 1978), was not sighted in the present study, probably due to its preference for colder waters (Aguayo-Lobo et al. op. cit.).

The only record of Steno bredanensis for Chile comes from an individual sighted in the area of Botija (2430'S), off Antofagasta Region (Van Waerebeek \& Guerra, 1988) most probably corresponding to the Peruvian population, that extends to the south, particularly during "El Niño" events (Aguayo-Lobo et al. 1998a), penetrating Chilean waters in search of food. The present study took place during a cold, "Inter-El Niño" period, explaining the species absence.

The distribution of the small cetaceans indicates a close relationship with the oceanographic conditions of the upwelling system described by Hormazábal et al. (2001) for the study area.

Accordingly, the distributional scheme north of Tocopilla corresponds precisely with the upwelling zone characterized by Fuenzalida (1992) and Blanco et al. (2001), while off the Mejillones peninsula the abundance and diversity of the dolphins is associated with the intense upwelling plume of this area (Castilla et al. 2002). The effect of the Mejillones upwelling on the distribution and feeding of the sperm whale (Physeter macrocephalus) was analyzed previously by Rendell et al. (2004) and Flores (2005).

The ocean environment west of the upwelling fronts (west of $71^{\circ} \mathrm{W}$ ) displayed lower densities of groups and species of dolphins, here interpreted as response to the lower productivity of these more oceanic areas (Wyrtki, 1964; Fonseca \& Farías, 
Table 3. Latitudinal species composition (\%) changes.

\begin{tabular}{|c|c|c|c|c|c|c|c|c|}
\hline \multicolumn{9}{|c|}{ Individuals } \\
\hline Species & $\begin{array}{l}18^{\circ} 00^{\prime}- \\
18^{\circ} 59^{\prime}\end{array}$ & $\begin{array}{l}19^{\circ} 00^{\prime}- \\
19^{\circ} 59^{\prime}\end{array}$ & $\begin{array}{l}20^{\circ} 00^{\prime}- \\
20^{\circ} 59^{\prime}\end{array}$ & $\begin{array}{l}21^{\circ} 00^{\prime}- \\
21^{\circ} 59^{\prime}\end{array}$ & $\begin{array}{l}22^{\circ} 00^{\prime}- \\
22^{\circ} 59^{\prime}\end{array}$ & $\begin{array}{l}23^{\circ} 00^{\prime}- \\
23^{\circ} 59^{\prime}\end{array}$ & $\begin{array}{l}24^{\circ} 00^{\prime}- \\
24^{\circ} 59^{\prime}\end{array}$ & Total \\
\hline D. delphis & 75.19 & 2.65 & & 9.47 & & & 11.81 & 3.51 \\
\hline D. capensis & & 2.12 & & 20.30 & & & 3.15 & 2.77 \\
\hline G. macrorhynchus & 5.26 & & & 2.30 & 10.07 & 1.36 & 3.94 & 2.02 \\
\hline G. griseus & 7.52 & & & 6.77 & 3.02 & 1.51 & & 2.21 \\
\hline L. obscurus & & & 16.39 & & 5.03 & 10.67 & & 8.22 \\
\hline L. peronii & & & & & & 18.42 & 58.27 & 15.10 \\
\hline S. coeruleoalba & & & & & & 0.38 & & 0.26 \\
\hline T. truncates & 12.03 & 84.66 & 65.57 & 44.52 & 76.51 & 62.00 & 21.66 & 59.60 \\
\hline Indet. & & 10.58 & 18.03 & 9.12 & 5.37 & 5.67 & 1.18 & 6.32 \\
\hline \multicolumn{9}{|c|}{ Herds } \\
\hline Species & $\begin{array}{l}18^{\circ} 00^{\prime}- \\
18^{\circ} 59^{\prime}\end{array}$ & $\begin{array}{c}19^{-\circ} 00^{\prime}- \\
19^{\circ} 59^{\prime}\end{array}$ & $\begin{array}{l}20^{\circ} 00^{\prime}- \\
20^{\circ} 59^{\prime}\end{array}$ & $\begin{array}{l}21^{\circ} 00^{\prime}- \\
21^{\circ} 59^{\prime}\end{array}$ & $\begin{array}{l}22^{\circ} 00^{\prime}- \\
22^{\circ} 59^{\prime}\end{array}$ & $\begin{array}{l}23^{\circ} 00^{\prime}- \\
23^{\circ} 59^{\prime}\end{array}$ & $\begin{array}{l}24^{\circ} 00^{\prime}- \\
24^{\circ} 59^{\prime}\end{array}$ & Total \\
\hline D. delphis & 20.00 & 20.00 & & 5.88 & & & 10.00 & 3.60 \\
\hline D. capensis & & 20.00 & & 5.88 & & & 10.00 & 2.70 \\
\hline G. macrorhynchus & 20.00 & & & 5.88 & 14.29 & 9.09 & 10.00 & 8.11 \\
\hline G. griseus & 20.00 & & & 11.76 & 7.14 & 4.55 & & 5.41 \\
\hline L. obscurus & & & 6.25 & & 7.14 & 15.91 & & 8.11 \\
\hline L. peronii & & & & & & 15.91 & 20.00 & 8.11 \\
\hline S. coeruleoalba & & & & & & 2.27 & & 0.90 \\
\hline T. truncatus & 40.00 & 40.00 & 62.50 & 52.94 & 57.14 & 34.09 & 30.00 & 44.14 \\
\hline Indet. & & 20.00 & 31.25 & 17.65 & 14.29 & 18.18 & 20.00 & 18.92 \\
\hline
\end{tabular}

1987; Morales et al. 1996; Hormazábal et al. 2001; Hormazábal \& Shaffer, 2002; Schneider et al. 2003; Fuenzalida et al. 2007).

The here found species and their abundances coincide in their specific structures as much as in relative abundances with the species assemblage cited by Van Waerebeek et al. (1988) for the Peruvian coast, including the subsequent additions of Lissodelphis peronii made by Lazarte \& Valdivia (1998) ) and Van Waerebeek et al. (1991). Peponocephala electra, a strongly oceanic species scarce off the Peruvian coast (Van Waerebeek et al. op cit.) was not found off the Chilean coast. Stenella attenuata and S. longirostris, tropical species that do not reach south of $21,5^{\circ} \mathrm{S}$ (Perrin, 1975) were also not found in the study area.

Therefore, the here found species assemblage is part of the same species group common to the
Peruvian coast, characterized fundamentally by the abundance of Tursiops truncatus (over $40 \%$ of the sightings and over $60 \%$ of the individuals sighted) (Van Waerebeek et al. (1991) for Peruvian data and present Table 3 for Chilean data).

The conservation status of most of the here involved species is "insufficiently known" (Delphinus delphis, D. capensis, Globicephala macrorhynchus, Grampus griseus and Lagenorhynchus obscurus), the coastal ecotype of Tursiops truncatus is "in danger" and the resting population of the same species "insufficiently known" (Ministerio de Medio Ambiente, 2020).

The present sighting rates (sightings/day) of $L$. obscurus, $L$. peronii and $T$. truncatus showed higher sighting rates $(1,02,1,02$ and 5,58 sightings/day respectively), as compared 
Table 4. Sighting rates of herds (herds/day) and specimens (specimens/day) off Northern Chile.

\begin{tabular}{|c|c|c|c|c|c|c|c|c|c|c|c|c|}
\hline \multicolumn{13}{|c|}{ Specimens/day } \\
\hline Campaign & Dates & Days & $D d$ & $D c$ & $\mathrm{Gm}$ & $G g$ & Lo & $L p$ & $S c$ & $T t$ & indet. & Totals \\
\hline 1 & $\begin{array}{c}28 / 03 \text { - } \\
17 / 04\end{array}$ & 21 & 1.43 & 0.38 & & 1.43 & 0.92 & & & 0.95 & 5.62 & 10.76 \\
\hline 2 & $\begin{array}{c}25 / 04- \\
16 / 05\end{array}$ & 21 & 0.24 & & 0.33 & & 1.43 & & & 17.14 & 1.62 & 20.76 \\
\hline 3 & $\begin{array}{c}24 / 05- \\
14 / 06\end{array}$ & 22 & 4.55 & & & & 1.82 & & & 3.68 & 0.05 & 10.09 \\
\hline 4 & $\begin{array}{c}26 / 06- \\
09 / 07\end{array}$ & 14 & & & & & 1.29 & 5.21 & 1.07 & 9.29 & 7.14 & 7.14 \\
\hline 5 & $\begin{array}{c}14 / 07- \\
03 / 08\end{array}$ & 21 & & & 0.71 & 1.43 & & 12.05 & & 0.05 & 0.05 & 14.29 \\
\hline 6 & $\begin{array}{c}18 / 08- \\
05 / 09\end{array}$ & 19 & & & 3.42 & 0.47 & & & & 13.53 & & 17.42 \\
\hline 7 & $\begin{array}{c}26 / 09- \\
17 / 10\end{array}$ & 12 & & 12.83 & & 5.00 & 0.17 & 37.92 & & 1.58 & 0.83 & 58.33 \\
\hline 8 & $\begin{array}{c}26 / 10- \\
13 / 11\end{array}$ & 9 & & & 3.44 & & 38.89 & 11.22 & & 260.11 & & 313.67 \\
\hline 9 & $\begin{array}{c}22 / 11- \\
10 / 12\end{array}$ & 19 & 3.68 & & & & 1.05 & & & 14.32 & 5.53 & 24.58 \\
\hline Totals & $\begin{array}{c}28 / 03- \\
10 / 12\end{array}$ & 158 & 1.30 & 1.03 & 0.75 & 0.80 & 3.04 & 5.58 & 0.095 & 22.03 & 2.34 & 36.97 \\
\hline \multicolumn{13}{|c|}{ Herds/day } \\
\hline Campaign & Dates & Days & $D d$ & $D c$ & $G m$ & $G g$ & Lo & $L p$ & Sc & $T t$ & indet. & Totals \\
\hline 1 & $\begin{array}{c}28 / 03- \\
17 / 04\end{array}$ & 21 & 0.05 & 0.05 & & 0.10 & 0.05 & & & 0.05 & 0.28 & 0.57 \\
\hline 2 & $\begin{array}{c}25 / 04- \\
16 / 05\end{array}$ & 21 & 0.05 & & $0, .05$ & & 0.14 & & & 0.62 & 0.19 & 1.05 \\
\hline 3 & $\begin{array}{c}24 / 05- \\
14 / 06\end{array}$ & 22 & 0.05 & & & & 0.05 & & & 0.36 & 0.05 & 0.50 \\
\hline 4 & $\begin{array}{c}26 / 06- \\
09 / 07\end{array}$ & 14 & & & & & 0.07 & 0.14 & 0.07 & 0.36 & 0.36 & 1.00 \\
\hline 5 & $\begin{array}{c}14 / 07- \\
03 / 08\end{array}$ & 21 & & & 0.05 & 0.05 & & 0.10 & & 0.05 & 0.05 & 0.29 \\
\hline 6 & $\begin{array}{c}18 / 08- \\
05 / 09\end{array}$ & 19 & & & 0.21 & 0.05 & & & & 0.21 & & 0.47 \\
\hline 7 & $\begin{array}{c}26 / 09- \\
17 / 10\end{array}$ & 12 & & 0.17 & & 0.17 & 0.08 & 0.25 & & 0.25 & 0.08 & 1.00 \\
\hline 8 & $\begin{array}{c}26 / 10- \\
13 / 11\end{array}$ & 9 & & & 0.33 & & 0.11 & 0.22 & & 0.01 & & 1.56 \\
\hline 9 & $\begin{array}{c}22 / 11 \text { - } \\
10 / 12\end{array}$ & 19 & 0.05 & & & & 0.05 & & & 0.32 & 0.16 & 0.58 \\
\hline Totals & $\begin{array}{c}28 / 03- \\
10 / 12\end{array}$ & 158 & 0.03 & 0.02 & 0.06 & 0.04 & 0.06 & 0.06 & 0.01 & 0.31 & 0.13 & 0.70 \\
\hline
\end{tabular}


Table 5 . Herd size by species.

\begin{tabular}{ccccc}
\hline Species & Herds (n) & Range (specimens) & Mean $(\overline{\mathrm{X}})$ & $\begin{array}{c}\text { Standar } \\
\text { desviation (std) }\end{array}$ \\
\hline$G m$ & 9 & $5-25$ & 12.0 & 9.06 \\
$G g$ & 6 & $9-30$ & 14.7 & 8.62 \\
$T t$ & 49 & $1-1500$ & 36.1 & 45.76 \\
$D d$ & 4 & $5-105$ & 51.3 & 21.75 \\
$D c$ & 3 & $4-150$ & 54.0 & 67.90 \\
Lo & 9 & $2-350$ & 22.6 & 9.94 \\
$S c$ & 1 & 15 & - & - \\
$L p$ & 9 & $1-250$ & 122.5 & 112.06 \\
\hline
\end{tabular}

to values of $0.13,0.13$ and 0.76 sightings/day respectively for the same species, indicated by Aguayo-Lobo et al. (op. cit.). Making a difference $D$. delphis with 1.01 sightings/day for the Valparaíso-Easter Island sector (Aguayo-Lobo et al. 1998b) is less abundant in the present study area (0.34 sightings/day).

T. truncatus, the most abundant species off the northern part of Chile (20 $\left.0^{\circ} 11^{\prime} S-32^{\circ} 13^{\prime} \mathrm{S}\right)$, reached up to 306.940 animals/day comparable to 309.20 animals/day found by Hucke-Gaete (1998) for the coast of central Chile and by Aguayo-Lobo et al. (1998a) between Valparaíso and Easter Island.

The sighting rate of $L$. obscurus in the present study area (38,96 animals/day, Cruise 8) than values reported for the littoral zone of central Chile (Aguayo-Lobo et al. 1998a; Findlay et al. 1998). The maximum sighting rate here found for L. peronii (37.9 animals/day, Cruise 7) compared with previous research data: 180 animals/day (January 1998, south of $40^{\circ}$ latitude) (Findlay et al. op. cit.) and 122,6 animals/day (Aguayo 1966) is consequent with the appreciation of Aguayo (op. cit.) suggesting that the species would be most abundant in the area south of the country.

These comparisons are not strictly comparable due to different years between this work and previous research. Also the present campaigns were carried out in autumn, winter and spring, while Hucke-Gaete (1998) did it in summer and Aguayo-Lobo et al. (1998b) in winter for the Valparaíso to Easter Island section. Therefore, it must be considered that new studies and future surveys in upwelling areas will corroborate or modify the present conclusions.

\section{ACKNOWLEDGEMENTS}

The study took place aboard the yacht "Balaena" within the framework of the projects "The geography and evolution of vocal clans in South Pacific sperm whales", directed by Dr. Henry Paine Whitehead, University Dalhousie, Halifax, Nova Scotia, Canada, and "Spatial-temporal distribution of cetacean species living or visiting the marine waters in the north of Chile", led by Dr. Anelio Aguayo-Lobo, Chilean Antarctic Institute; and the program "Evaluation of the Biodiversity of Northern Chile" of the Department of Marine Sciences, Universidad Arturo Prat, Chile.

We thank Dr. Henry Paine Whitehead for making available his yacht "Balaena" to the study, to Dr. Luke Rendell, captain and chief scientist of the cruise, for his support and participation in obtaining the data of this study, to our colleagues and marine biologists Jorge Acevedo and Francisco Viddi, and the students Carolina Lippi, María José Pérez, Marcelo Flores and Leah Bedje who were part of the observation shifts and assisted during the fields work.

Special thanks to Dr. Gene C. Feldman, Responsible NASA Official, Curator Ocean Color Website, for his help with Sea-viewing Wide Fieldof-view Sensor (SeaWiFS) Ocean Color Data, and providing historical images of March 2000.

\section{LITERATURE CITED}

Aguayo, A. (1966). Observaciones de cetáceos frente a la costa de Chile, durante el año 1966. Informe al Ministerio de Agricultura (Departamento de Pesca y Caza). Montemar, 
Chile. Informe Técnico. $11 \mathrm{pp}$.

Aguayo, A. (1975). Progress report on small cetacean research in Chile. Journal of the Fisheries Research Board of Canada, 32(7), 1123-1143.

Aguayo-Lobo, A. (1999). Los cetáceos y sus perspectivas de conservación. Estudios Oceanológicos, 18, 35-43.

Aguayo-Lobo, A., Torres, D., \& Acevedo, J. (1998a). Los mamíferos marinos de Chile:

I. Cetacea. Serie Científica, Instituto Nacional Antártico de Chile (INACH), 48, 19-159.

Aguayo-Lobo, A., Bernal, R., Olavarria, C., Vallejos, V., \& Hucke-Gaete, R. (1998b). Observaciones de cetáceos realizadas entre Valparaíso e isla de Pascua, Chile, durante los inviernos de 1993, 1994 y 1995. Revista de Biología Marina, 33(1), 101123.

Aguayo-Lobo A., Whitehead, H., Rendell, L., Acevedo, J., Vallejos, V., Bedje, L., Moraga, R., Atalah, J., Buscaglia, M., Flores, M., González, E., Lippi, C., Pérez, M. J., Vargas, R, \& Viddi, F. (2002). Distribución espacio- temporal de las especies de cetáceos registrados frente a las costas del norte de Chile, Arica (18 $\left.38^{\circ} \mathrm{S}\right)$ y sur de Taltal (2530'S), durante el año 2000. En Libro de resúmenes. $10^{\mathrm{a}} \mathrm{RT}$ y $4^{\circ}$ Congreso SOLAMAC, 14-19 de Octubre, Valdivia, Chile p. 25-26.

Barlow, J., \& Forney, K.A. (2007). Abundance and population density of cetaceans in the California Current ecosystem. Fishery Bulletin, 105, 509-526.

Barnes, R. S. K., \& Hughes, R. N. (1988). An Introduction to Marine Ecology. $2^{\text {nd }}$. Edition. Blackwell Scientific Publications.

Blanco, J. L., Thomas, Z. C., Carr, M. E., \& Strub, P. T. (2001). Seasonal climatology of hydrographic conditions in the upwelling region off northern Chile. Journal of Geophysical Research, 106(6), 11.45111.467.

Böhm, G., Hernández, C., Díaz, E., Pérez, G., \& Ojeda, R. (2017). Programa de seguimiento de las principales pesquerías pelágicas de la zona norte de Chile, XV-IV Regiones, año 2016. Instituto de Investigación Pesquera, Chile. Boletín Informativo, 33 pp.

Camus, P. (2001). Marine biogeography of continental Chile. Revista Chilena de Historia Natural, 74, 587-617.

Canto, J., Ruiz, P., \& Yáñez, J. (1992). Registro de nuevas especies de cetáceos para la costa de Chile y antecedentes del grupo. Boletín Museo Nacional de Historia Natural, Chile, 43, 105-115.

Cárdenas, J. C., Stutzin, M., Oporto, J., Cabello, C., \& Torres, D. (1986). Manual de Identificación de los cetáceos chilenos. Comité pro Defensa Flora y Fauna (CODEFF), Santiago, $102 \mathrm{pp}$.

Cárdenas, J. C., Yáñez, J., Reyes, J. C., \& Van Waerebeek, K. (1991). Nuevos registros de cetáceos para el Archipiélago de Juan Fernández, Chile. Boletín Museo Nacional de Historia Natural, Santiago de Chile, 42, 113-120.

Carretta, J. V., Forney, K. A., Muto, M. M., Barlow, J., Baker, J., Hanson, B., \& Lowry, M. S. (2006). U.S. Pacific Marine Mammal Stock Assessments: 2005. NOAA Technical Memorandum, NMFS-SWFSC, 388, 1-317.

Castilla, J. C., Lagos, N. Guiñez, N. A., \& Largier, J. L. (2002). Embayments and nearshore retention of plankton: The Antofagasta Bay and other Examples. In J. C. Castilla \& J. L. Largier (Eds.), The oceanography and ecology of the nearshore and bays in Chile (pp. 179-203). Ediciones Universidad Católica de Chile.

CCTPP (Comité Científico Técnico de Pesquerías de Pequeños Pelágicos). (2014). Determinación del estado de situación y rango de captura biológicamente aceptable de recursos pelágicos pequeños Año 2015. Informe Técnico 01/2014. 28 pp.

Clarke, R. (1962). Whale observation and whale marking off the coast of Chile in 1958 and from Ecuador towards and beyond the Galapagos Islands in 1959. Norsk Hualfangst. Tidende, 51(7), 265-287.

Clarke, R., Aguayo, A., \& Basulto, S. (1978). Whale observation and whale marking off the coast of Chile in 1964. The Scientific 
Reports of the Whales Research Institute, 30, 117-177.

Culik, B. M. (2004). Review of Small Cetaceans. Distribution, Behaviour, Migration and Threats. United Nations Environment Programme (UNEP) and the Secretariat of the Convention on the Conservation of Migratory Species of Wild Animals (CMS), Bonn, Germany. Marine Mammal Action Plan/Regional Seas Reports and Studies $\mathrm{N}^{\circ}$ $177 \mathrm{pp}$.

Daneri, G., Dellarossa, V., Quiñones, R., Jacob, B., Montero, P., \& Ulloa, O. (2000). Primary production and community respiration in the Humboldt Current System off Chile and associated oceanic areas. Marine Ecology Progress Series, 197, 41-49.

Escribano, R., \& McLaren, I. (1999). Production of Calanus chilensis in the upwelling area of Antofagasta, northern Chile. Marine Ecology Progress Series, 177, 147-156.

Escribano, R., Marín, V. H., Hidalgo, P., \& Olivares, G. (2002). Physical-biological interactions in the pelagic ecosystem of the nearshore zone of the Northern Humbold Current System. In J. C. Castilla \& J. L. Largier (Eds.), The oceanography and ecology of the nearshore and bays in Chile (pp. 145179). Ediciones Universidad Católica de Chile.

Escribano, R., Hidalgo, P., \& Krautz, C. (2009). Zooplancton associated with the oxygen minimum zone system in the upwelling region of Chile during March 2000. Deep Sea Research II, 56(2009), 1083-1094.

Findlay, K., Pitman, R., Tsurui, T., Sakai, K., Ensor, P., Iwakami, H., Ljungblad, D., Shimada, D., Thiele, D., Van Waerebeek, K., Hucke-Gaete, R., \& Sanino, G.P. (1998). 1997/1998 IWC-Southern Whale and Ecosystem Research (IWC/SOWER) Blue Whale Cruise, Chile. Documento Técnico, IWC, May 1998. Muskat, Oman, 39 pp.

Flores, M. (2005). Patrón de distribución de unidades sociales de cachalote Physeter macrocephalus, frente a las costas de la I y II Regiones de Chile. Tesis de Biólogo Marino. Universidad de Valparaíso, 70 pp.

Fonseca, T. (1989). An overview of the Poleward
Undercurrent and upwelling along the Chilean coast. In S.J. Neshyba, C.N.K. Mooers, R.L. Smith \& R.T. Barber (Eds.), Poleward flows along Eastern Ocean Boundaries (pp. 203-228). Springer-Verlag.

Fonseca, T., \& Farías, M. (1987). Estudio del proceso de surgencia en la costa chilena utilizando percepción remota. Investigaciones Pesqueras, 34, 34-46.

Fuenzalida, R. (1992). Proceso de surgencia en la Región Norte de Chile latitudes 2030'S-2145'S. Revista de Investigaciones Científicas y Tecnológicas. Serie Ciencias del Mar, 2, 79-104.

Fuenzalida, R., Schneider, W., Blanco, J. L., Garcés, J., \& Bravo, L. (2007). Chile-Peru Current System and Water Masses between Caldera and Easter Island. Ciencia del Mar, 30(2), 5-16.

Gallardo, V. A., \& Pastene, L. (1983). Observaciones cetológicas frente a Chile central entre $32^{\circ} \mathrm{S}$ y $38^{\circ} 30^{\prime} \mathrm{S}$. Ciencia y Tecnología del Mar, CONA, 7, 141-154.

González J., Capella, J., \& Gibbons, J. (1989). Delfines nariz de botella Tursiops truncatus (Montagu, 1821) habitando frente a Isla Chañaral, Provincia de Huasco, Chile. Estudios Oceanológicos, 8, 67-71.

Graham, W. M., \& Largier, J. L. (1997). Upwelling shadows as nearshore retention sites: the example of Monterey Bay. Continental Shelf Research, 17, 509-532.

Guerra, C., Van Waerebeek, K., Portflitt, G., \& Luna, G. (1987a). The short-finned Pilot Whale Globicephala macrorhynchus Gray, 1846, the first record for Chile. Estudios Oceanológicos, 6, 97-102.

Guerra, C., Van Waerebeek, K., Portflitt, G., \& Luna, G. (1987b). Presencia de cetáceos frente a la Segunda Región de Chile. Estudios Oceanológicos, 6, 87-96.

Hammer, O. (2018). PAST. PAleontological STatistics Version 3.21 Reference Manual. 264 pp.

Hormazábal, S., \& Shaffer, G. (2002). Tropical Pacific control of intraseasonal oscillations off Chile by way of oceanic and atmospheric pathways. Geophysical Research Letters, 29(6), 1-4. 
Hormazábal, S., Shaffer, G., Letelier, J., \& Ulloa, O. (2001). Local and remote forcing of sea surface temperature in the coastal upwelling system off Chile. Journal of Geophysical Research, 106, 16.657-16.671.

Hoyt, E. (1999). Guía de campo de las ballenas, delfines y marsopas. En M. Carwardine, E. Hoyt, E. Fordyce \& P. Gill (Eds.), Ballenas, delfines y marsopas (pp.15-280). Editorial Planeta.

Hucke-Gaete, R. (1998). Crucero de investigación sobre la ballena azul (Balaenoptera musculus) en aguas chilenas. IWC/ SOWER 1997/1998. Technical Report, Valdivia, $15 \mathrm{pp}$.

Hucke-Gaete, R. (2000). Review of the conservation status of small cetaceans in southern South America, 24 pp. UNEP/ CMS Secretariat, Bonn.

Lagos, N., Barría, I. D., \& Paolini, P. (2002). Upwelling ecosystem of Northern Chile: integrating benthic ecology and coastal oceanography through remote sensing. In J.C. Castilla \& J. L. Largier (Eds.), The oceanography and ecology of the nearshore and bays in Chile (pp. 117-141). Ediciones Universidad Católica de Chile..

Lazarte, A., \& Valdivia, J. (1998). Nuevo registro de Lissodelphis peronii (Lacepede, 1804) al norte de los $10^{\circ}$ L.S. Abstract, IX Congreso Nacional de Biología, 27 November - 2 December 1998, Perú: Piura.

Leatherwood, S., Reeves, R. R., \& Foster, L. (1983). The Sierra Club Handbook of Whales and Dolphins. Sierra Club Books San Francisco. Tien Wah Press Singapore.

Letelier, J., Soto-Mardones, L., Salinas, S., Vincenti, L., Pavez, R., \& Arriagada, M. (2012). Influence of the Mejillones peninsula in the annual and interannual oceanographic variability off northern Chile. Revista de Biología Marina y Oceanografía, 47(3), 513-526.

Marín, V. H., \& Moreno, C. (2002). Wind driven circulation and larval dispersal: a review of its consequences in coastal benthic recruitment. In J. C. Castilla \& J. L. Largier (Eds.), The oceanography and ecology of the nearshore and bays in Chile (pp.
47-63). Santiago: Ediciones Universidad Católica de Chile.

Marín, V., Delgado, L., \& Escribano, R. (2003). Upwelling shadows at Mejillones Bay (northern Chilean coast): a remote sensing in situ analysis. Investigaciones Marinas, 31(2), 47-55.

Marín, V.H., Escribano, R., Delgado, L.E., Olivares, G., \& Hidalgo, P. (2001). Nearshore circulation in a coastal upwelling siter off the northern Humboldt Current System. Continental Shelf Research, 21, 1317-1329.

Marzloff, M. P., \& Tam, J. (2011). MSC Low Trophic Level Project: Ecosystem impacts of fishing low trophic level groups Northern Humboldt Current case study. Marine Stewardship Council Science Series, 1, 19-53.

Ministerio del Medio Ambiente (MMA). 2020. Clasificación de especies según estado de conservación. https://clasificacionespecies. mma.gob.cl/. Aceeded 13.oct. 2020.

Morales, C. E., Blanco, J. L., Braun, M., Reyes, H., \& Silva, N. (1996). Chlorophyll- $\alpha$ distribution and associated oceanographic conditions in the upwelling region off northern Chile during the winter spring 1993. Deep Sea Research, 43, 267-289.

Perrin, W.F. (1975). Distribution and differentiation of populations of dolphins of the genus Stenella in the eastern tropical Pacific. Journal of the Fisheries Research Board of Canada, 32, 1059-1067.

Perrin, W. F. (2002). Common dolphins. In W. F. Perrin, P. Würsig \& J. G. M. Thewisen (Eds.), Encyclopedia of marine mammals (pp. 245-248). Academic Press.

Rendell, L. E., Whitehead, H., \& Escribano, R. (2004). Sperm whale habitat use and foraging success off northern Chile: Evidence of ecological links between coastal and pelagic systems. Marine Ecology Progress Series, 275, 289-295. https://doi.org/10.3354/ meps275289

Rodríguez, L., Marín, V. H., Farías, M., \& Oyarce, E. (1991). Identification of an upwelling zone by remote sensing and in situ measurements, Mejillones del Sur Bay (Antofagasta-Chile). 
Scientia Marina, 545, 467-473.

Rojas, P. M., Escribano, R., \& Marín, V. H. (2002). Fish larvae distribution off Mejillones Peninsula (northern Chile) during a coastal upwelling event in Spring 1999: interactions with the cold upwelling plume. Fisheries Oceanography, 11, 233-244.

Sanino, G. P., Van Waerebeek, K., \& Yáñez, J. (2003a). Revisión de la distribución del género Delphinus y registros documentados de Delphinus capensis en Chile. Boletín del Museo Nacional de Historia Natural, Chile, 52, 97-102.

Sanino, G. P., Van Waerebeek, K., \& Yáñez, J. (2003b). Estudio de restos varados de Delphinus delphis y primer registro documentado de pneumonia focal abscedativa, en Chile. Boletín del Museo Nacional de Historia Natural, Chile, 52, 103-117.

Shaffer, G., Pizarro, O., Djurfeld, L., Salinas, S., \& Ruttland, J. (1997). Circulation and low-frequency variability near the Chilean coast: Remotely forced fluctuations during the 1991-1992 El Niño. Journal Physical Oceanography, 27, 217-235.

Schneider, W., Fuenzalida, R., Rodríguez-Rubio, E., Garcés-Vargas, J., \& Bravo, L. 2003. CharacteristicsandformationofeasternSouth Pacific Intermediate Water. Geophysical Research Letters, 30(11), 1581. https:// doi.org/10.1029/2003GL017086.

Sielfeld, W. (1983). Mamíferos marinos de Chile. Santiago: Ediciones de la Universidad de Chile. 1-199 pp.

Sielfeld, W., Aguayo-Lobo, A., \& Acevedo, J. (2003). Primer registro osteológico de Delphinus capensis Gray, 1828 en la costa de Tarapacá, Norte de Chile. Noticiero Mensual, Museo Nacional de Historia Natural, Santiago de Chile, 352, 11-17.

Sielfeld, W., Laudien, J., Vargas, M., \& Villegas, M. (2010). El Niño induced changes of the coastal fish fauna off northern Chile and implications for ichthyogeography. Revista Biología Marina y Oceanografía, 45, S.1, 705-722.

Silva, N. (1983). Masas de agua y circulación en la región norte de Chile. Latitudes $18^{\circ} \mathrm{S}-$ $32^{\circ} \mathrm{S}$ (operación oceanográfica MARCHILE XI-ERFEN II). Ciencia y Tecnología del Mar, 7, 47-84.

Sobarzo, M., \& Figueroa, D. (2001). The physical structure of a cold filament in a Chilean upwelling zone (Peninsula de Mejillones, Chile, 23ㅇ). Deep Sea Research I, 48, 2699-2726.

Strub, T., Mesías, J., Montecino, V., Rutllant, J. \& Salinas, S. (1998). Coastal ocean circulation off Western South America. Coastal segment. In A. R. Robinson \& K. H. Brink (Eds.), The Sea, II (273-313). John Wiley \& Sons.

SUBPESCA. (2016). Recursos anchoveta y sardina española y su pesquería entre la XV y II Regiones. División de Administración Pesquera, 46 pp. http://www.subpesca.cl/ portal/616/articles-97330_documento.pdf

Thiel, M., Macaya, E. C., Acuña, E., Arntz, W., Bastías, H., Brokordt, K., Camus, P. A., Castilla, J. C., Castro, L. R., Cortés, M., Dumont, C. P., Escribano, R., Fernández, M., Gajardo, J. A., Gaymer, C. F., Gómez, I., González, A. E., González, H. E., Haye, P. A., ... \& Alonso, J.M. (2007). The Humboldt Current System of Northern and Central Chile. Oceanographic processes, ecological interactions and socioeconomic feedback. Oceanography and Marine Biology: An Annual Review, 45, 195-344.

Torres, R., Turner, D., Silva, N., \& Ruttland, J. (1999). High-shot term variability of $\mathrm{CO}_{2}$ fluxes during an upwelling event off the Chilean coast at $30^{\circ}$ S. Deep Sea Research I, 46, 1161-1179.

Trites, A. W., Christensen, V., \& Pauly, D. (1997). Competition between fisheries and marine mammals for prey and primary production in the Pacific Ocean. Journal of Northwest Atlantic Fishery Science, 22, 173-187.

Trowbridge, J. H., Chapman, D. C., \& Candela, J. (1998). Topographic effects, straits and the bottom boundary layer,. In A.R. Robinson \& K. H. Brink (Eds.), The Sea, vol. 10 (pp. 63-88). Wiley \& Sons.

Van Waerebeek, K., \& Guerra, C. (1987). Review of the distribution and status of the Burmeister's porpoise in Chile. Report: Cetacean survey in II Region of Chile, August-September 
1986. In D. E. Gaskin \& A. J. Read (Eds.). (1988). Exploitation and biology of small cetaceans in the coastal waters of Peru and Northern Chile (pp. 42-58). IUCN/ UNEP(OCA)-PSE-MM/DPPS IC 1/34.

Van Waerebeek, K., \& Guerra, C. (1988). A southern record of the rough-toothed dolphin, Steno bredanensis, in the eastern Pacific. Estudios Oceanológicos, 7, 75-79.

Van Waerebeek, K., Reyes, J., \& Luscombe, B. (1988). Revisión de la distribución de pequeños cetáceos frente a Perú. Boletín del Instituto del Mar del Perú, Volumen Extraordinario, 345-351.

Van Waerebeek, K., Canto, J., González, J., Oporto, J., \& Brito, J.L. (1991). Southern right whale dolphins, Lissodelphis peronii off the Pacific coast of South America. Zeitschrift für Säugetierkunde, 56, 284-295.
Vergara, J. (1991). La surgencia costera a la latitud de $30^{\circ} \mathrm{S}$ : un estudio numérico. Revista de Biología Marina y Oceanografía, 20(2), 375-401.

Vergara, J. (1992). Simulación de evento de surgencia costera a los $29,5^{\circ} \mathrm{S}$. Chile. Investigaciones Pesqueras, 37, 73-87.

Vincenty, T. (1975). Direct and Inverse Solutions of Geodesics on the Ellipsoid with application of nested equations. Survey Review, XXIII (176),88-93. https://doi.org/10.1179/ sre.1975.23.176.88

Whitehead, H. (2003). Sperm whales: Social evolution in the ocean (First Edition) (pp. 1-456). Chicago University Press.

Wyrtki, K. (1964). Total integrated mass transports and actual circulation in the eastern South Pacific Ocean. Studies in Oceanography, 47-52. 


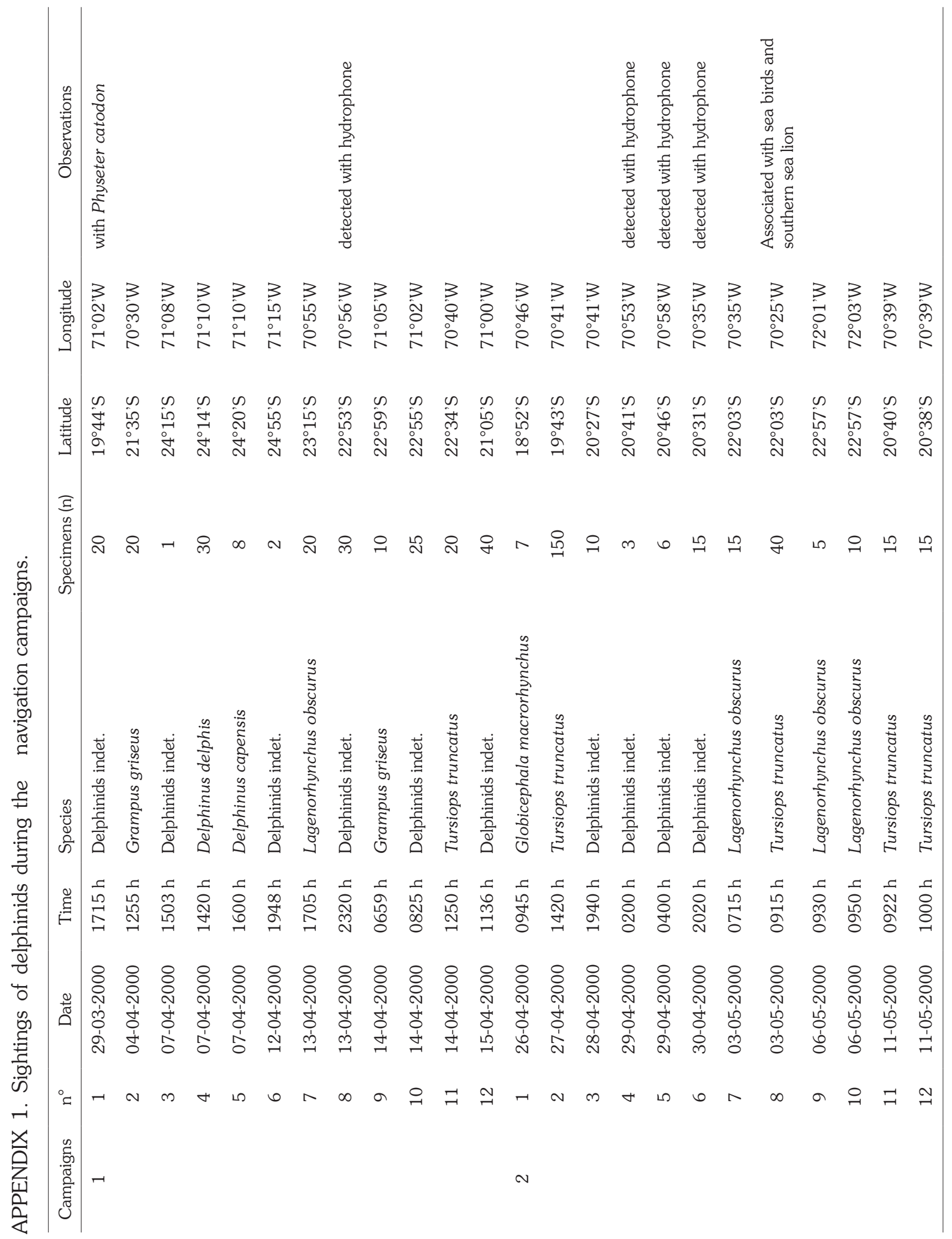




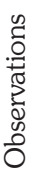

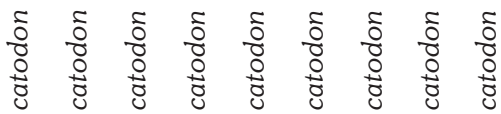

$\frac{\sqrt{0}}{4}$

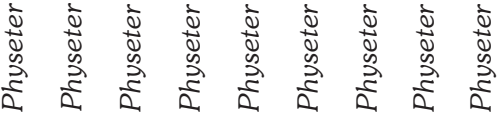

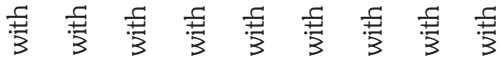

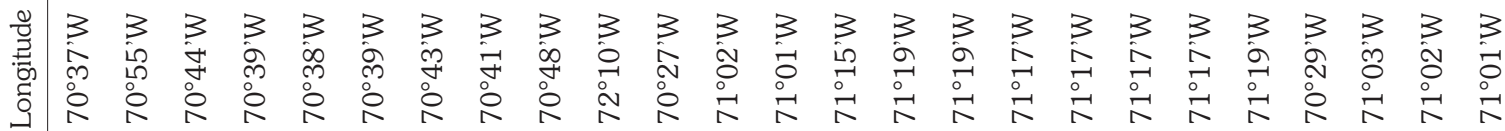

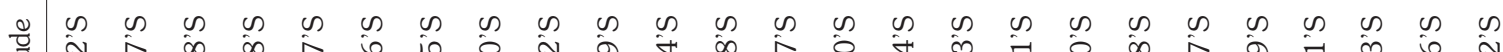
丞

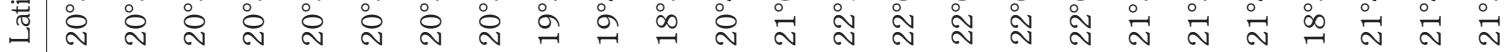
로

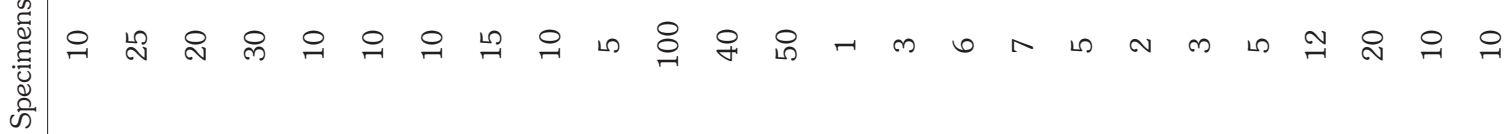

空

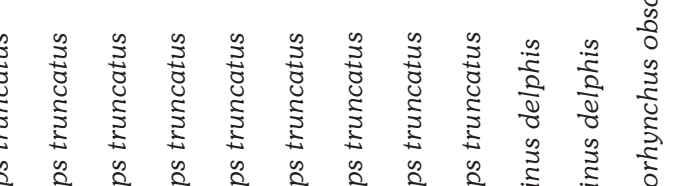

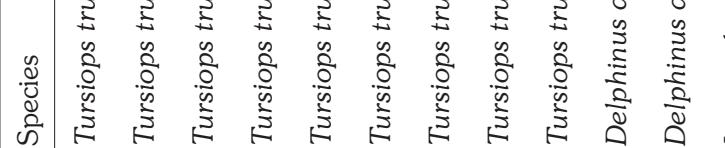

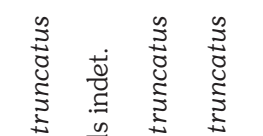

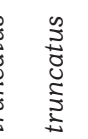

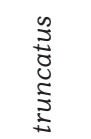

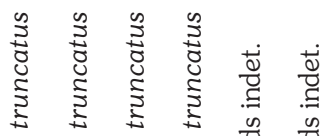

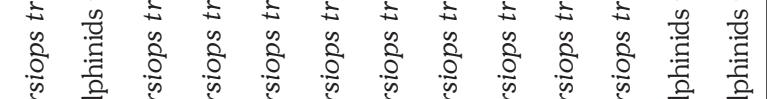

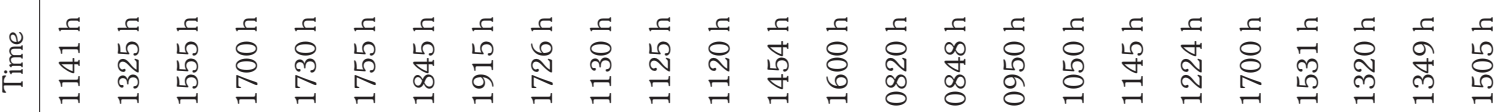

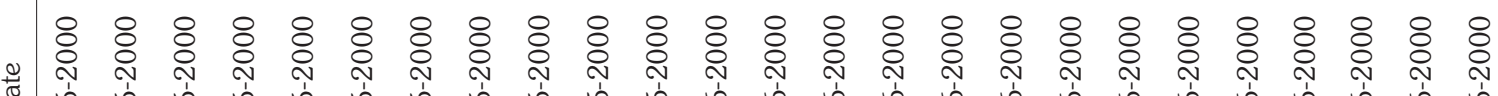
苋

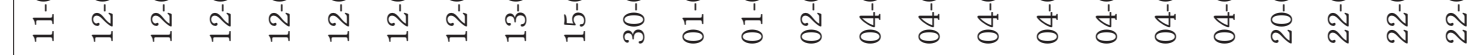

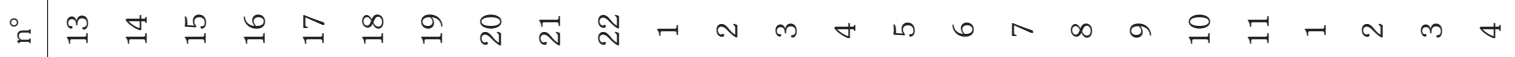
苛 


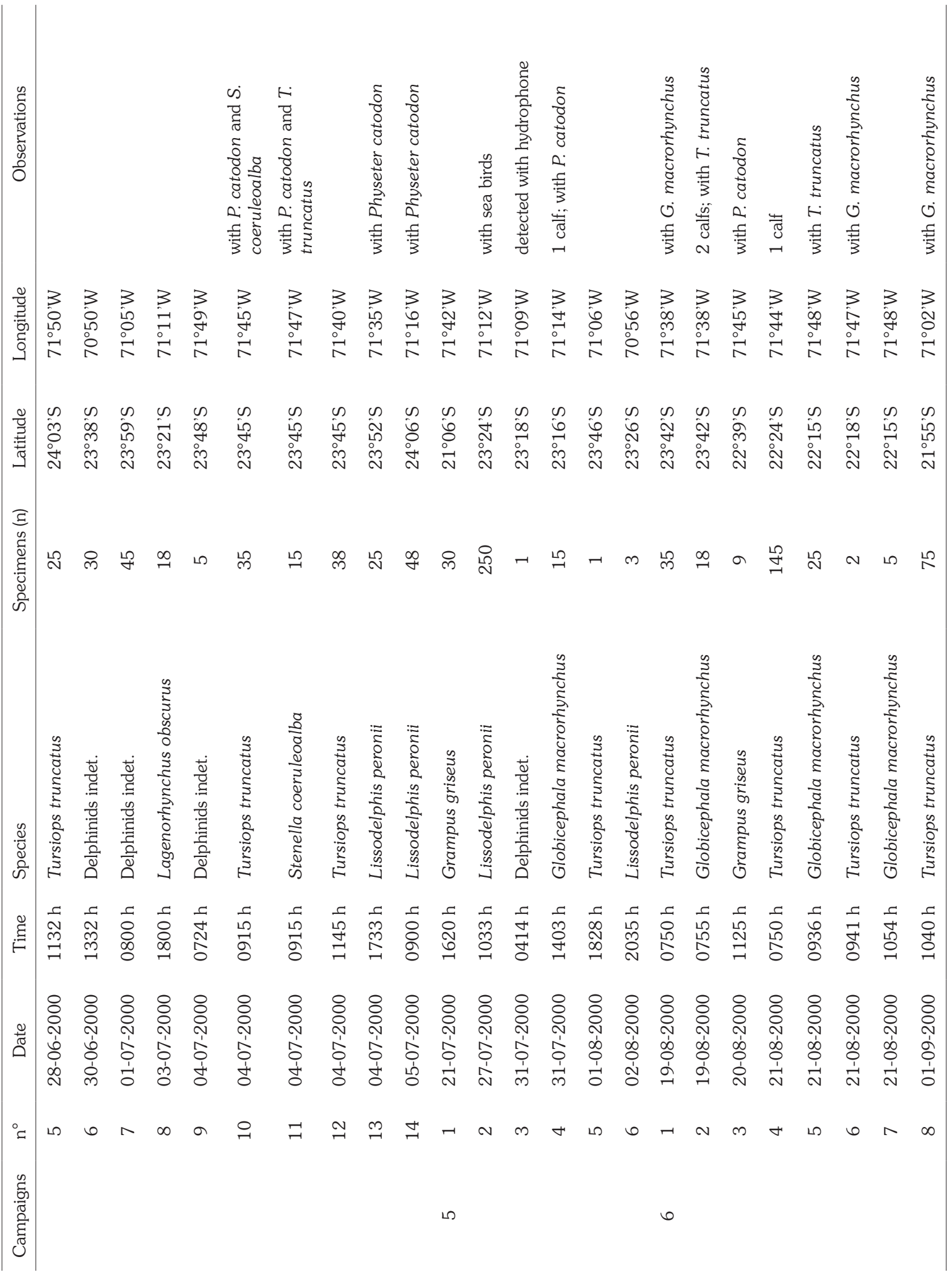




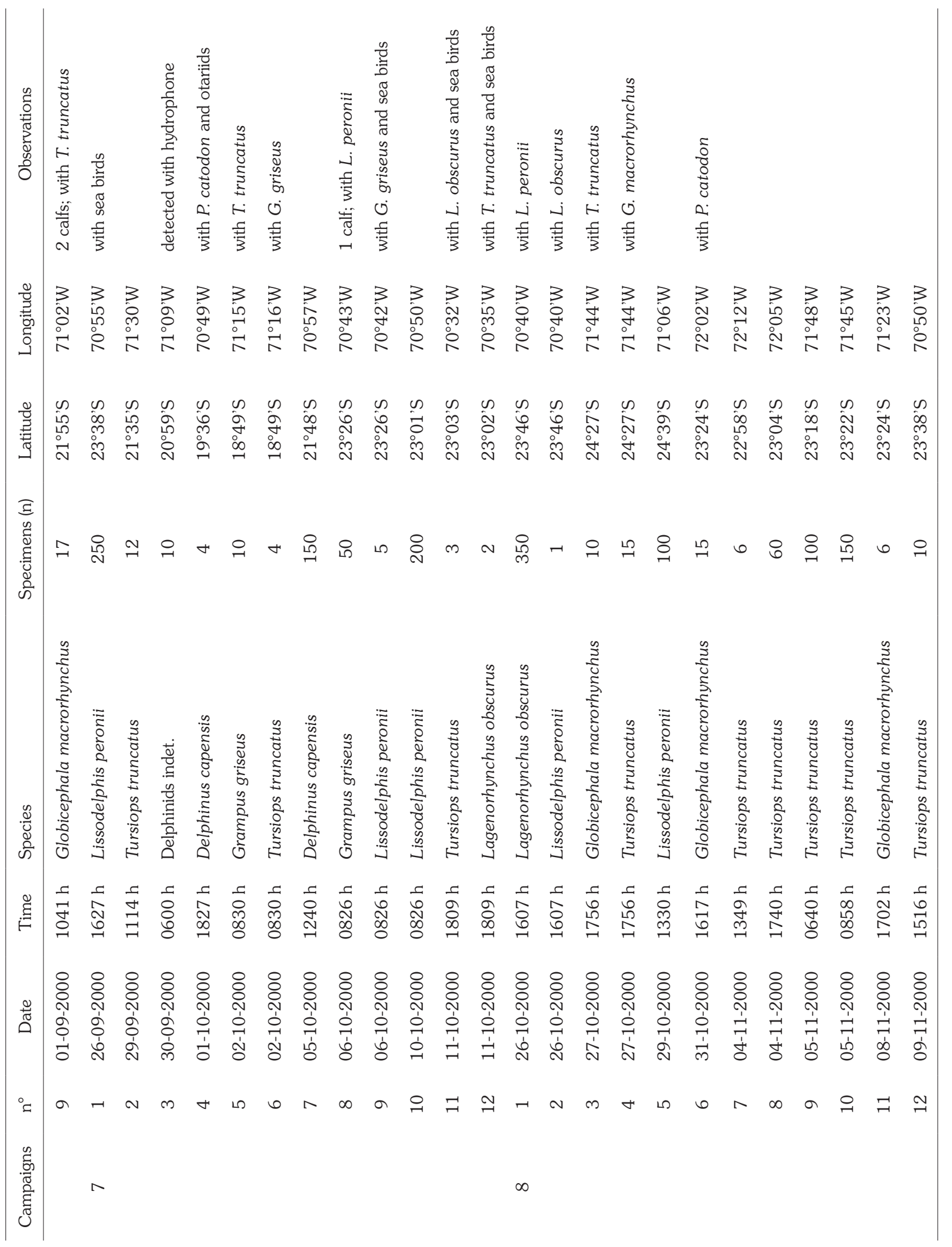




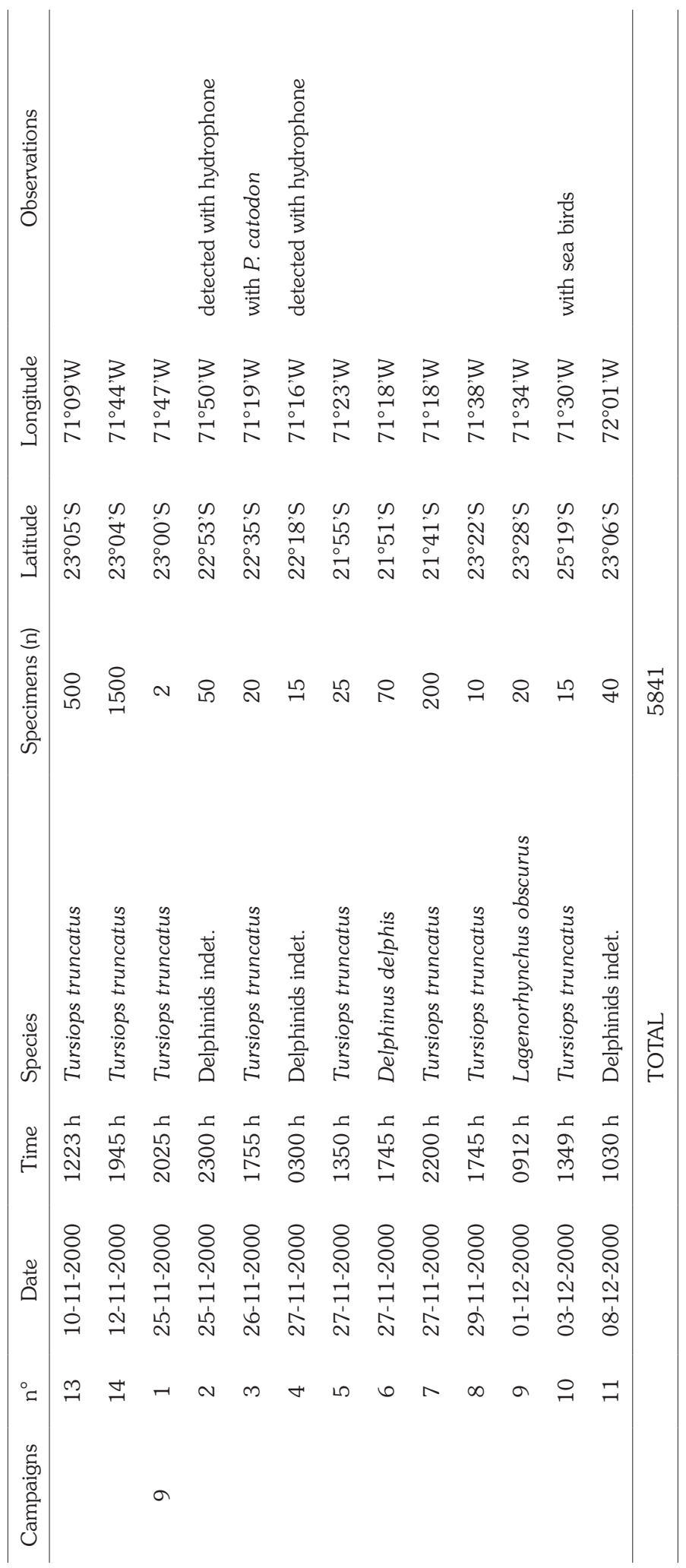

